\title{
Kakovost \\ v izobraževanju odraslih
}

Zadnja desetletja znova in znova ponavljamo, da v sodobni, hitro spreminjajoči se družbi znanje ne more biti več le privilegij manjšine, ampak postaja vse bolj nujnost ter potreba za preživetje in normalno delovanje posamezni$k a v$ družbeni skupnosti. Nova paradigma $v$ izobraževanju, katere srž najdemo v potrebi po vseživljenjskem učenju, na področje izobraževanja odraslih vnaša nove razsežnosti in postavlja izobraževalce odraslih pred nove izzive ter odgovornosti.

Iz opazovanja družbenega dogajanja je očitno, da so se na povečano povpraševanje odraslih po znanju $v$ zadnjem desetletju izobraževalci odraslih zelo hitro odzvali z razširjeno ponudbo izobraževalnih storitev, ki se kaže tudi $v$ razvoju novih izobraževalnih programov za različne ciljne skupine odraslih. Odgovor na porast brezposelnosti $v$ zadnjem desetletju je tudi razvoj različnih izobraževalnih programov za izobraževanje brezposelnih. $Z$ vključevanjem vanje naj bi si brezposelni pridobili znanje, ki bi povečalo njihove možnosti za zaposlitev, zato se razvijajo novi programi usposabljanja in izpopolnjevanja za različne poklice. Da bi se čimbolj približali vsem tistim posameznikom, ki povprašujejo po zelo različnih vrstah znanja, se razvijajo novi pristopi $k$ učenju in fleksibilnejše in bolj odprte oblike ter metode dela. Med takšnimi oblikami učenja so se pri nas že dokaj uveljavili študijski krožki. Središča za samostojno učenje ponujajo individualizirane izobraževalne programe, prilagojene posamezniku in njegovim potrebam. Tudi borze znanja, $k i$ omogočajo srečevanje tistih, ki imajo določeno znanje, in tistih, ki po njem povprašujejo,

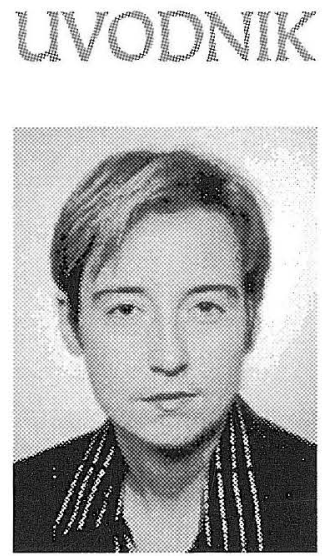

Tanja Možina so pri odraslih dobro sprejete. Čedalje več pozornosti se namenja tudi izobraževalnim potrebam starejšega prebivalstva in razvoju tovrstne izobraževalne dejavnosti.

Takšno dogajanje na področju izobraževanja odraslih kaže na obdobje, ko je bilo treba zagotoviti novo izobraževalno infrastrukturo, ustvariti možnosti za uveljavljanje novih pristopov ter oblik dela in razviti nove izobraževalne programe za nove cilje skupine odraslih. $V$ zadnjem času pa je vse pogosteje slišati vprašanja o tem, ali imamo $v$ zvezi s takšnim povečanjem izobraževalnih storitev za odrasle razvite pristope, ki nam bi omogočali tudi spremljanje njihove kakovosti. Če želimo zagotoviti, da bo izobraževalna ponudba zares kakovostna, moramo izobraževalci odraslih najprej sami poiskati odgovore na vprašanja, kot so: kaj odlikuje dobrega učitelja $v$ izobraževanju odraslih, kako organizirati izobraževalni proces, da bodo pri tem upoštevane značilnosti in potrebe odraslih, kako se lotiti ugotavljanja kakovosti znanja, ki si ga pridobijo udeleženci $v$ različnih oblikah izobraževanja, kako pripraviti učno gradivo, da bo udeležencem $v$ pomoč pri samostojnem učenju, kako vključiti udeležence v načrtovanje lastnega izobraževanja?

Na podlagi pregleda izobraževalnih strategij razvitih izobraževalnih sistemov ugotavljamo, da bomo morali v prihodnje v Sloveniji, če se bomo želeli s temi uspešnimi sistemi primerjati tudi po kakovosti pridobljenega znanja, storiti še marsikaj. Naša strokovna prizadevanja bo treba pri nadaljnjem razvoju med drugim usmeriti tudi v oblikovanje celovitega 
pristopa spremljanja kakovosti dela. V ta namen je treba najprej zagotoviti, da bodo vsi novi sistemski mehanizmi in institucije, ki smo jih pridobili $v$ zadnjih desetih letih, tudi zares učinkovito in aktivno opravljali svojo vlogo pri skrbi za kakovost dela na področju izobraževanja odraslih. Zato je najprej potreben konsenz o temeljnih kazalcih kakovosti, ki jih je treba spremljati na ravni izobraževalnega sistema, če hočemo zagotoviti preglednost posameznih delov.

Sočasno pa je treba oblikovati celovit in sistematičen pristop $k$ ugotavljanju in razvoju kakovosti na ravni izobraževalne organizacije za odrasle oziroma ponuditi izobraževalnim organizacijam strokovno podporo pri uvajanju mehanizmov, s katerimi bodo same sistematično skrbele za kakovost lastnega delovanja. Večja avtonomija, ki jo v skladu z novo normativno ureditvijo pridobivajo izobraževalne organizacije in se bo v prihodnje povečevala hkrati z udejanjanjem procesa decentralizacije izobraževalnega sistema, namreč od izobraževalcev odraslih zahteva nove odgovornosti. Odgovornost se kaže tudi v sistematičnem spremljanju kakovosti lastnega dela in zmožnosti, da v vsakem trenutku lahko pokažemo, kaj in kako delamo ter koliko smo pri svojem delu uspešni. Če želimo, da bo takšen celovit pristop tudi zares zaživel med izobraževalci odraslih, je treba pri njegovem snovanju vanj vgraditi izkušnje, ki jih je v preteklosti za spremljanje kakovosti lastnega dela andragoška praksa že razvila.

Da bi združili različne tovrstne pobude, ki smo jim v zadnjih letih priča na področju izobraževanja odraslih, je Andragoški center Slovenije 16. in 17. maja 2000 organiziral strokovni posvet Kakovost v izobraževanju odraslih. Posvet je bil zamišljen kot strokovno srečanje in izmenjava izkušenj ter pogledov na kakovost tistih strokovnjakov, ki se z izobraževanjem odraslih ukvarjajo v praksi, in tistih, ki področje preučujejo in razvijajo na teoretski oziroma razvojno-raziskovalni ravni. Takšna zasnova posveta se je izkazala kot dobra, saj se je v razpravah, ki so se zvrstile v zvezi z različnimi temami, pokazal pomen nenehnega prepletanja in primerjanja pogledov teoretikov in praktikov ter konstruktivnega sodelovanja pri skrbi za kakovosten razvoj izobraževanja odraslih.

V tokratni številki Andragoških spoznanj vam predstavljamo nekatere zanimive prispevke, $s$ katerimi so se na posvetu predstavili različni avtorji. Nekaj jih bomo predstavili tudi v naslednjih številkah. Prispevki s posveta kažejo na potrebo po interdisciplinarnem pristopu $k$ skrbi za kakovost dela v izobraževanju odraslih. To potrjuje tudi interdisciplinarnost samega področja. Na posvetu so namreč poleg andragogov sodelovali tudi ekonomisti, managererji, pedagogi, sociologi idr. Različno mišljenje, različna mnenja in različni pristopi so pokazali, da smo tudi na področju izobraževanja odraslih že dodobra zajadrali v čas, $v$ katerem je treba ustvariti možnosti za sobivanje različnih resnic, načinov in poti za doseganje skupnih ciljev.

Razpravljalci so precejšnjo pozornost namenili kakovostnemu vodenju in upravljanju izobraževalnih organizacij. Sodobni sistemi kakovosti so hkrati sistemi vodenja, je bilo slišati na posvetu. Izobraževalni sistem in izobraževalno organizacijo odlikujejo jasna vizija razvoja izobraževanja odraslih, jasno začrtani cilji, odprtost $v$ mednarodni prostor in razvita kultura vseživljenjskega učenja. Ta bo omogočala doseganje zastavljenih ciljev, kritično refleksijo in razvoj. Nekateri razpravljalci so se dotaknili soodvisnosti področja izobraževanja odraslih in trga dela. Opozarjali so na potrebo po uvajanju mehanizmov za ugotavljanje izobraževalnih potreb in predvsem na pritegnitev delodajalcev ter drugih partnerjev $v$ oblikovanje kakovostnih izobraževalnih storitev za odrasle.

Razpravljalci, ki so zastopali ekonomsko 
področje, pa tudi sociologi in managerji, so poudarjali predvsem makroekonomske dejavnike in šrřse družbene vplive, ki jih je treba upoštevati pri presoji kakovosti izobraževanja odraslih, izobraževalci pa predvsem različne vidike kakovosti samega izobraževalnega procesa: opozorili so na potrebo po organiziranem in sistematičnem svetovalnem delu $z$ odraslimi udeleženci ter na potrebo po uporabi aktivnih oblik in metod dela z odraslimi. Zanimiva razprava se je razvila tudi $v$ zvezi $z$ razmišljanji o vplivih in posledicah, ki jih prinašajo sodobne metode preverjanja in ocenjevanja znanja ter sprotnega spremljanja napredka udeleženca izobraževanja. Na posvetu je bil velik poudarek tudi na sodelovanju izobraževalnih organizacij $v$ mednarodnih projektih in programih. To sodelovanje je bilo predstavljeno na eni strani kot izziv, možnost in priložnost, ki jo prinašajo novi projekti Evropske unije, na drugi strani pa kot nujnost in potreba, pred katero nas postavlja sodobna globalizacija, pri čemer se kakovost dela čedalje bolj meri tudi s kazalci kakovosti sodelovanja in povezovanja izobraževalnega sistema ter izobraževalnih organizacij $v$ širšem smislu. Globalizacija hkrati zahteva upoštevanje mednarodnih standardov kakovosti, ki omogočajo primerljivost izobraževalnih organizacij $v$ širšem evropskem prostoru, morebitnim partnerjem $v$ skupnih mednarodnih projektih pa omogočajo zanesljive informacije o kakovosti izobraževalne organizacije, s katero naj bi sodelovali.

Bogastvo raznolikih pogledov na kakovost se je pokazalo tudi $v$ dokaj uravnoteženem prispevku tistih, ki so odgovore o najboljših možnih pristopih iskali v različnih teoretskih konceptih in ki so razgrinjali različne konceptualne ter terminološke vidike razprav o kakovosti, in tistih, ki so prihajali iz izobraževalne prakse in predstavljali konkretne ter preizkušene operativne rešitve za povečevanje kakovosti.
Še največ nasprotnih mnenj smo lahko na posvetu ugotovili pri razpravah o uvajanju že oblikovanih sistematičnih modelov za spremljanje kakovosti v izobraževalno organizacijo, kot so standardi ISO, model TQM oziroma njegova evropska različica model poslovne odličnosti. V razpravah v tem sklopu so predstavili svoja mnenja tisti, ki so tovrstne modele že vpeljali v svoje izobraževalne organizacije in ki na podlagi lastnih izkušenj menijo, da so koristni ter ustrezni, in tisti, ki so do tovrstnih modelov, še posebej takšnih, ki se v izobraževanje odraslih prenašajo iz gospodarstva, skeptični in ki v njih vzbujajo dvome. Morda se vam bodo pri prebiranju različnih prispevkov zdele nekatere ponujene konceptualne ter operativne rešitve sprejemljive in boste v njih prepoznali lastno prakso, morda vas bodo drugi napeljali $k$ razmišljanju o možnostih in potrebi uvajanja že preizkušenih rešitev $v$ vašo dejavnost. Nekatere vam bodo morda vzbudile nove strokovne dileme ali pa nestrinjanje. Kakorkoli že bodo v vas odzvanjala sporočila različnih avtorjev, skušajte jih brati z vidika njihove uporabnosti pri prizadevanjih za oblikovanje celovitega in sistematičnega pristopa $h$ kakovosti v izobraževanju odraslih. To namreč lahko zaživi le, če bomo izobraževalci odraslih $v$ sodelovanju s strokovnjaki iz drugih disciplin vnaprej pripravljeni prevzemati aktivno vlogo in prispevati svoje raznoliko znanje. Rezultati različnih mednarodnih raziskav, med katere spada tudi raziskava o pismenosti odraslih, pri čemer smo Slovenci pristali na zelo nezavidljivem mestu, so lahko vsem nam velik izziv za to, da združimo moči v skupnem strokovnem delovanju na tem področju. Enega izmed možnih izhodov iz takega nezavidljivega položaja lahko prav gotovo iščemo v razvoju bolj sistematičnih pristopov $h$ kakovosti različnih dejavnikov v izobraževanju odraslih.

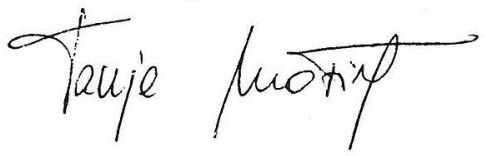

